\title{
THE LATERAL BUCKLING OF SIMPLY SUPPORTED UNRESTRAINED BISYMETRIC I-SHAPE BEAMS
}

\begin{abstract}
R. BIJAK ${ }^{1}$
The analytical approach is used for checking the stability of laterally unrestrained bisymmetric beams. The stability equations for simply supported beams are solved approximately using the Bubnov-Galerkin method [4]. The lateral buckling moment depends on bending distribution and on the load height effect. Each of applied concentrated and distributed loads, may have arbitrary direction and optional coordinate for the applied force along the cross section's height. Derived equations allow for simple, yet fast control of lateral buckling moment estimated by FEM [15].
\end{abstract}

Keywords: lateral buckling moment, simply supported beams with free warping, bisymmetric I-shaped beams, analytical solution.

\section{INTRODUCTION}

There are three major issues existing as it concerns an estimation of value of lateral-torsional critical moment:

1. Assumption of proper boundary conditions at the ends of considered member. In presented work simply supported beams is analyzed - the most common case in design practice.

2. Taking into account non-linear bending moment distributions along the element. Its influence is evaluated on basis of values of bending moment is some discrete points of the beam span (literally $1 / 4,1 / 2,3 / 4$ of the beam span) and the maximum absolute value of the

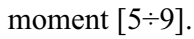

3. Effect of position of load application with respect to height of the element cross-section.

\footnotetext{
${ }^{1}$ DSc., Kielce University of Technology, Faculty of Civil Engineering and Architecture, Al. 1000-lecia PP 7, 25-314 Kielce, Poland, e-mail: r.bijak@wp.pl
} 
Considering any, arbitrary static diagram, the most difficult seems to be point (3). It was found, in available literature, only two approaches of solving this problem. Trahair et al. [7] assumed for arbitrary load formula being correct if there were no concentrated moments applied, Helwig et al. [10] presented modification of $C_{1}$ coefficient (see eq. 2.1) derived on basis of numeric simulations. The analytical approach is used for estimation of lateral buckling moment in simply supported bisymmetrical I-shaped beams. In order to analyze it, differential equation of flexural-torsional buckling (with respect to twist angle) is solved with help of Bubnov-Galerkin method Important feature of this work, in comparison to other authors' papers $[4,5,7,10]$ is derivation of formulas for calculation of critical moment coefficients taking into account position of the transverse load with respect to height of the cross-section for any, arbitrary structural arrangement. Comparing to previous paper [11] of the author, there is also extension, consisting in fact, that each of applied loads, may have arbitrary direction. Significant contribution of this paper is taking into account the above mentioned parameters in the simple analytical solution.

\section{EXISTING DESIGN CODE PROCEDURE}

For beams of double symmetric cross-section the value of lateral buckling moment may be computed using the expression:

$$
M_{0, c r}=C_{1} N_{c r, z}\left(\sqrt{D+\left(C_{2} z_{g}\right)^{2}}+C_{2} z_{g}\right)
$$

$$
N_{c r, z}=\frac{\pi^{2} E I_{z}}{L^{2}}, \quad D=D_{1}+D_{2}, \quad D_{1}=\frac{I_{w}}{I_{z}}, \quad D_{2}=\frac{G I_{T}}{N_{c r, z}}
$$

where: $L$ - beam length, $I_{z}$ - principal moment of inertia about $z$ axes, $I_{T}-$ St. Venant torsion constant, $I_{w}-$ warping constant, $E$ - Young's modulus, $G$ - shear modulus.
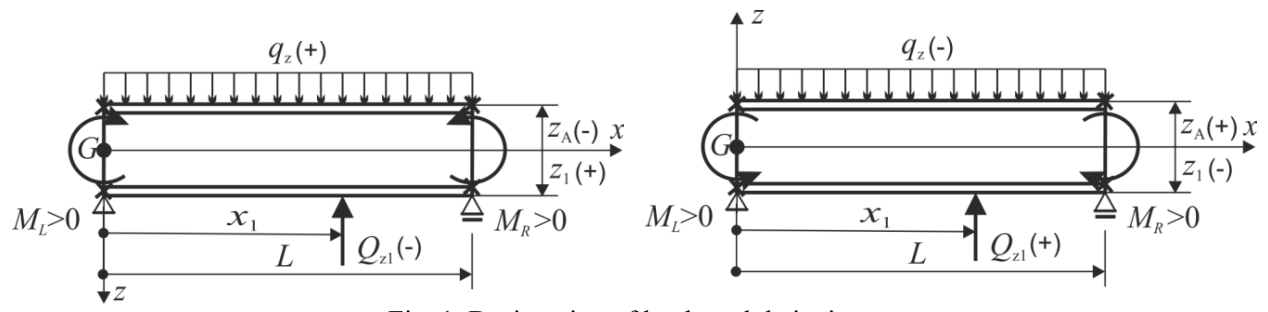

Fig. 1. Designation of loads and their signs 
In simple cases, coefficients $C_{1}$ and $C_{2}$ are given in [4,11]. In case of any, arbitrary distribution of bending moment, coefficient $C_{1}$ may be evaluated on basis of absolute values of bending moments in sampling points (AISC [6]):

$$
C_{1}=\frac{12,5 M_{0}}{2,5 M_{0}+3 M_{2}+4 M_{3}+3 M_{4}} \text { but } C_{1} \leq 2,27 \text {, }
$$

where: $M_{2}, M_{3}$ and $M_{4}$ - absolute values of bending moments at $x=L / 4, L / 2,3 L / 4$

$M_{0}$ - max. absolute value of bending moment $\left(M_{0}=\max \left|M_{\mathrm{y}}(x)\right|\right.$ for $\left.0 \leq x \leq L\right)$.

Equation (2.3) is some modification of dependency shown by Kirby, Nethercot [5].
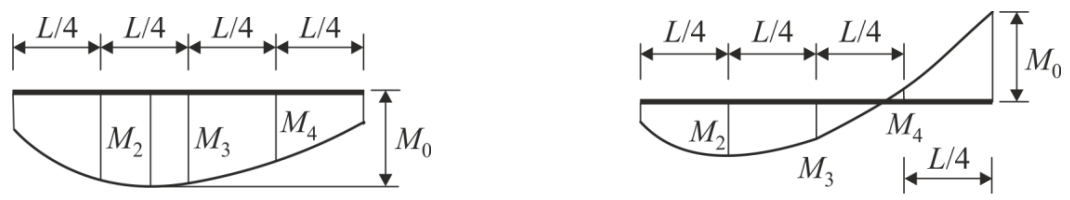

Fig. 2. Values of bending moments in eq. $(2.3 \div 5)$

Australian standard AS 4100 employs the following formula:

$$
C_{1}=\frac{1,7 M_{0}}{\sqrt{M_{2}^{2}+M_{3}^{2}+M_{4}^{2}}} \text { but } C_{1} \leq 2,5,
$$

which is parallel to equation presented by Trahair et al.[7].

Recently, Serna et al. [9] has shown approximation formula:

$$
C_{1}=\sqrt{\frac{35 M_{0}^{2}}{M_{0}^{2}+9 M_{2}^{2}+16 M_{3}^{2}+9 M_{4}^{2}}}
$$

In order to take into account position of the load with respect to height of the cross-section Trahair et al. [7] proposed the following relationship:

$$
C_{2}=0.4 C_{1}
$$




\section{GENERAL METHOD FOR UNRESTRAINED SIMPLY SUPPORTED BISYMMETRIC I-SHAPE BEAMS}

Let's consider the simply supported beam, loaded by the moments applied to its ends and the loads at span (Fig. 1). The center of gravity of the cross-section is denoted as $G$ and coincides with the shear center. Each of applied concentrated and distributed loads, may have any direction (positive/negative) and optional "vertical" coordinate of point where load is applied with respect to the cross section's height. Derived relationships are correct for both coordination systems shown in Fig.1.In case of simply supported, prismatic bisymmetric I-section beams with unrestrained warping at the ends, the lateral buckling problems are formulated as stability differential equations in terms of torsion angle $\varphi(\mathrm{x})$ (Fig. 1)[4]:

$$
-\frac{\left[M_{y}^{b}(x)\right]^{2}}{E I_{z}} \varphi+E I_{w} \varphi^{(4)}-G I_{T} \varphi^{(2)}+F^{b}(x)=0
$$

where:

$\varphi^{(\mathrm{k})}=\partial^{\mathrm{k}} \varphi / \partial x^{\mathrm{k}}-$ denotes $k$-th derivative with respect to $x$ and upper index $b$ refers to appropriate parameters in buckling state.

In the case of bending moment $M_{y}(x)$ it can be written ( $\mu_{c r}$ is critical load multiplier):

$$
M_{y}^{b}(x)=\mu_{c r} M_{y}(x)
$$

Function $F^{b}(x)$ determines the influence of ordinate of point of load application with respect to height of the cross-section:

$$
F^{b}(x)=\mu_{c r}\left[q_{z}(x) z_{A} \varphi+\sum_{k=1}^{N} Q_{z k} z_{k} \Delta\left(x-x_{k}\right) \varphi\right]
$$

where:

$q_{\mathrm{z}}(x)$ - distributed load in the $z$ direction, $N$ - the number of point forces, $Q_{\mathrm{zk}}-\mathrm{k}^{\text {th }}$ concentrated load in the $z$ direction, $x_{k}$ - coordinate of applied $k^{\text {th }}$ concentrated load along the beam axis, $z_{A}, z_{k}$ - load position parameters (Fig.1), $\Delta$-Dirac's function. 
Thus the equation (3.1), denoting $M_{0}^{b}=\mu_{c r} M_{0}$, may be written in form appropriate for any, arbitrary static scheme:

$$
-\left(M_{0}^{b}\right)^{2}\left[\frac{M_{y}(x)}{M_{0}}\right]^{2} \varphi+M_{0}^{b} N_{c r, z} A_{2 z}(x)+N_{c r, z}^{2}\left(D_{1} \frac{L^{4}}{\pi^{4}} \varphi^{(4)}-D_{2} \frac{L^{2}}{\pi^{2}} \varphi^{(2)}\right)=0
$$

$$
A_{2 z}(x)=\frac{L^{2}}{M_{0} \pi^{2}}\left[q_{z}(x) z_{A} \varphi+\sum_{k=1}^{N} Q_{z k} z_{k} \Delta\left(x-x_{k}\right) \varphi\right]
$$

The stability equations (3.2) are solved using the Galerkin orthogonalization method. In case of simply supported beams with free warping, sinusoidal mode is assumed for the torsion angle. The angle is approximated using only the first term of series. Performing necessary integration the lateral buckling moment is given by the roots of the quadratic equation.

$$
-a_{1}\left(M_{0}^{b}\right)^{2}+N_{c r, z} a_{2 z} M_{0}^{b}+N_{c r, z}^{2} D=0
$$

where:

$$
\begin{gathered}
a_{1}=\frac{2}{M_{0}^{2} L} \int_{0}^{L} M_{y}^{2}(x) \sin ^{2}(\pi x / L) d x>0 \\
a_{2 z}=\frac{2 L}{M_{0} \pi^{2}}\left[\int_{0}^{L} q_{z}(x) z_{A} \sin ^{2}(\pi x / L) d x+\sum_{k=1}^{N} Q_{z k} z_{k} \sin ^{2}\left(\pi x_{k} / L\right)\right]
\end{gathered}
$$

Equation (3.3) can be further converted into:

$$
\left(M_{0}^{b}\right)^{2}-2 C_{1} N_{c r, z} C_{2 z} M_{0}^{b}-C_{1}^{2} N_{c r, z}^{2} D=0
$$

where:

$$
C_{1}=\frac{1}{\sqrt{a_{1}}}, \quad C_{2 z}=C_{1} \frac{a_{2 z}}{2}
$$

Derived from the solution of quadratic equation (3.6) the value of critical moment is expressed as:

$$
M_{0}^{b}=C_{1} N_{c r, z}\left(C_{2 z} \pm \sqrt{D+C_{2 z}^{2}}\right)
$$


Because $M_{0}>0$, the lateral buckling moment is given by:

$$
M_{0, c r}=C_{1} \cdot N_{c r, z}\left(\sqrt{D+C_{2 z}^{2}}+C_{2 z}\right)
$$

The modification factor $C_{1}$ is function of bending moment distribution (from 3.4 and 3.7a):

$$
C_{1}=\frac{M_{0}}{\sqrt{\frac{2}{L} \int_{0}^{L} M_{y}^{2}(x) \sin ^{2}(\pi x / L) d x}}
$$

Please note that equations $(2.4 \div 2.5)$ are Simpson's-type approximations of integral (3.10).

a)

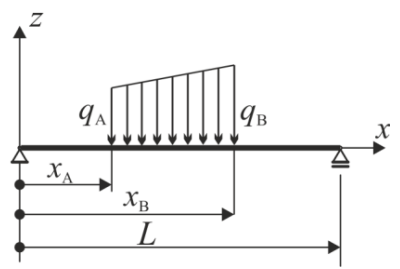

b)

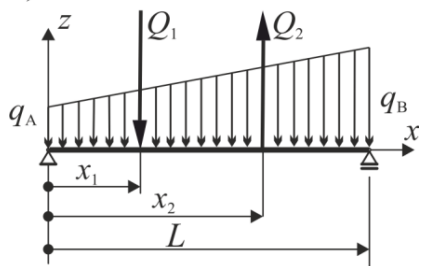

Fig. 3. a) Distributed load on part of the beam b) transverse load on whole beam span

For linearly distributed load applied to part of considered beam (Fig. 3a) integral in equation (3.5) can be calculated as follows:

$$
\begin{gathered}
\int_{0}^{L} q_{z}(x) \sin ^{2}(\pi x / L) d x=\frac{q_{B}+q_{A}}{4}\left(x_{B}-x_{A}\right)+ \\
+\frac{L}{4 \pi}\left[q_{A} \sin \left(\frac{2 \pi x_{A}}{L}\right)-q_{B} \sin \left(\frac{2 \pi x_{B}}{L}\right)\right]+\frac{L^{2}\left(q_{B}-q_{A}\right)}{8 \pi^{2}\left(x_{B}-x_{A}\right)}\left[\cos \left(\frac{2 \pi x_{A}}{L}\right)-\cos \left(\frac{2 \pi x_{B}}{L}\right)\right]
\end{gathered}
$$

In case of typical transverse load (Fig.3b) we have the following:

$$
a_{2 z}=\frac{2 L}{M_{0} \pi^{2}}\left[\frac{\left(q_{A}+q_{B}\right) L}{4} z_{A}+\sum_{k=1}^{N} Q_{z k} z_{k} \sin ^{2}\left(\pi x_{k} / L\right)\right]
$$




\section{EXAMPLES}

\section{Example 1.}

It is assumed steel ( $E=210 \mathrm{GPa}, G=81 \mathrm{GPa})$ beam of length $\mathrm{L}=8 \mathrm{~m}$ as shown in Fig. 4, cross-section of beam is IPE 500. According to [15] the following sectional properties were taken: $I_{z}=2141,7 \mathrm{~cm}^{4}$, $I_{T}=89,006 \mathrm{~cm}^{4}, I_{w}=1254,3 \cdot 10^{3} \mathrm{~cm}^{6}$. Load is applied to upper flange of IPE500 $\left(z_{\mathrm{g}}=-25 \mathrm{~cm}\right)$. Critical moment shown in tables below is expressed in $[\mathrm{kNm}]$.

In Table 1, there are shown differences of estimation of critical moment between FEA approach (LTBeam [15]), author's previous paper [11] and Trahair et al. [7] (eq.2.6).

a)

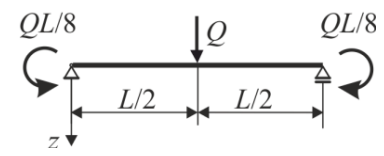

b)

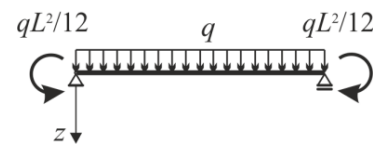

Fig. 4. Static scheme of considered beam (example 1)

Table 1. Comparison of values derived from Bijak [11], Trahair et al [7] and FEA [15].

\begin{tabular}{|c|c|c|c|c|c|c|c|c|c|c|}
\hline \multirow{3}{*}{$\begin{array}{l}\text { Lp } \\
1)\end{array}$} & \multirow{3}{*}{$\begin{array}{c}\begin{array}{c}\text { Static } \\
\text { diagram }\end{array} \\
\text { Fig.4a }\end{array}$} & \multirow{3}{*}{$\begin{array}{c}\text { LTBeam [15] } \\
215,3\end{array}$} & \multicolumn{4}{|c|}{ Bijak [11] Table 2} & \multicolumn{4}{|c|}{ Trahair et al. [7] Fig. 6.7} \\
\hline & & & \multirow{2}{*}{$\frac{\mathrm{C}_{1}}{1,70}$} & \multirow{2}{*}{$\frac{\mathrm{C}_{2}}{1,40}$} & \multicolumn{2}{|c|}{$\mathrm{M}_{\mathrm{cr}} / \mathrm{err} \%$} & \multirow{2}{*}{$\frac{\mathrm{C}_{1}}{1,71}$} & \multirow{2}{*}{$\frac{\mathrm{C}_{2}}{0,68}$} & \multicolumn{2}{|c|}{$\mathrm{M}_{\mathrm{cr}} / \mathrm{err} \%$} \\
\hline & & & & & 216,8 & $/ 0,7$ & & & 317,2 & $/ 47,3$ \\
\hline 2) & Fig.4b & 305,8 & 2,60 & 1,60 & 302,8 & $/-1,0$ & 2,42 & 0,97 & 382,5 & $/ 25,1$ \\
\hline
\end{tabular}

\section{Example 2.}

For the beam as in previous example it is assumed static scheme as shown in Fig. 5. Distributed load is applied at the top flange, point loads are applied at the top flange and at the bottom flange. In Table 2 it is shown error estimation of impact of position of the load.
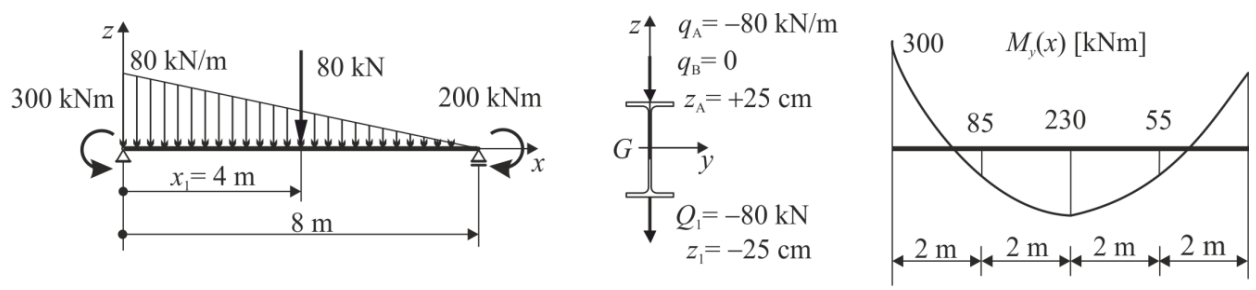

Fig. 5. Static scheme of considered beam (example 2) 
Table 2. Comparison of values derived from presented work and FEA [15] (Fig. 5)

\begin{tabular}{|c|c|c|c|c|c|c|c|c|}
\hline \multirow{2}{*}{$\mathrm{C}_{1}$ eq. (2.3) } & \multicolumn{6}{|c|}{ Load application point ordinate } \\
\cline { 2 - 9 } & \multicolumn{3}{|c|}{$\mathrm{z}_{\mathrm{A}}=25 \mathrm{~cm}, \quad \mathrm{z}_{\mathrm{Q} 1}=25 \mathrm{~cm}$} & \multicolumn{3}{c|}{$\mathrm{z}_{\mathrm{A}}=25 \mathrm{~cm}, \mathrm{z}_{\mathrm{Q} 1}=-25 \mathrm{~cm}$} \\
\cline { 2 - 9 } & $\begin{array}{c}\text { LTBeam } \\
{[15]}\end{array}$ & $\begin{array}{c}\mathrm{C}_{2 \mathrm{z}}[\mathrm{cm}] \\
(3.12,3.7 \mathrm{~b})\end{array}$ & $\begin{array}{c}\mathrm{M}_{\mathrm{cr}} \\
\text { eq. (3.9) }\end{array}$ & {$[\%]$} & $\begin{array}{c}\text { LTBeam } \\
{[15]}\end{array}$ & $\begin{array}{c}\mathrm{C}_{2 \mathrm{z}}[\mathrm{cm}] \\
(3.12,3.7 \mathrm{~b})\end{array}$ & $\begin{array}{c}\mathrm{M}_{\mathrm{cr}} \\
\text { eq. (3.9) }\end{array}$ & {$[\%]$} \\
\hline 1,794 & 258,5 & $-29,08$ & 256,7 & $-0,7$ & 401,0 & $-9,70$ & 395,2 & $-1,4$ \\
\hline
\end{tabular}

\section{Example 3.}

Let's then check error of estimation of coefficient $C_{1}$, computed from formulas $(2.3 \div 5)$. Transverse load is assumed to be applied at the centre of gravity $G$. In such case the critical moment can be calculated according to following formula:

$$
M_{0, c r}=C_{1} \cdot N_{c r, z} \sqrt{D}
$$

Let's introduce a parameter $\beta$ (4.2c), such, that $\beta=0$ means no point forces applied, and high value of $\beta$ means that there is very little influence of distributed loads. In turn, parameter $\psi(4.2 \mathrm{~d})$ determines measure of rigidity of support ( $\psi=0$ pin support, $\psi=1$ full restraint).

$$
(4.2 \mathrm{a} \div \mathrm{d}) \quad M_{q}=\frac{q L^{2}}{8}, \quad M_{Q}=\frac{Q L}{4}, \quad M_{Q}=\beta M_{q}, \quad M_{P}=\psi M
$$

In case of beam shown in Fig. 6a full restraint can be written as equation (4.3), whereas for the one shown in Fig. $6 \mathrm{~b}$ with formula (4.4).

$$
\begin{gathered}
M=\frac{2}{3} M_{q}+\frac{1}{2} M_{Q} \\
M=M_{q}+\frac{3}{4} M_{Q}
\end{gathered}
$$

a)

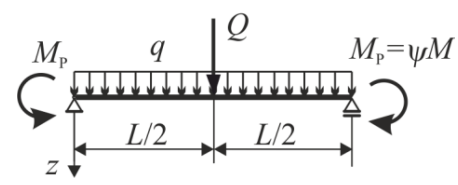

b)

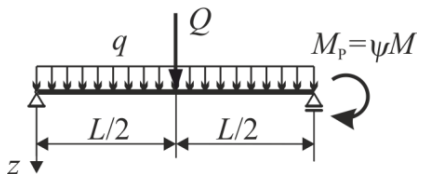

Fig. 6. Example 3. Static schemes of considered beam (a - Table 3, b-Table 4) 
Comparing the results in tables 3 and 4, one can see relatively small errors of approximation of critical moment calculated with the help of formulas $(2.3 \div 5)$. It is worth to mention, that errors of determined buckling factor would be even smaller. Results obtained from formula (2.3) seem to have the smallest errors.

Table 3. Comparison of values derived from formulas $2.3 \div 5$ and FEA [15], (load as in Fig. 6a).

\begin{tabular}{|c|c|c|c|c|c|c|c|c|c|c|}
\hline \multirow{5}{*}{$\begin{array}{l}\text { No. } \\
\\
1)\end{array}$} & \multirow{5}{*}{$\begin{array}{l}\psi \\
\\
\\
\\
0\end{array}$} & \multirow{3}{*}{$\begin{array}{c}\beta \\
0\end{array}$} & \multicolumn{8}{|c|}{ Critical moment $\mathrm{M}_{\mathrm{cr}}[\mathrm{kNm}] /$ relative error [\%] } \\
\hline & & & \multicolumn{2}{|c|}{$\begin{array}{l}\text { LTBeam } \\
{[15]}\end{array}$} & \multicolumn{2}{|c|}{$\begin{array}{c}\text { AS } 4100[8] \\
\text { (eq. } 2.4)\end{array}$} & \multicolumn{2}{|c|}{$\begin{array}{l}\text { Serna et al.[9] } \\
\quad(\text { eq. } 2.5)\end{array}$} & \multicolumn{2}{|c|}{$\begin{array}{l}\text { AISC [6] } \\
\text { (eq. 2.3) }\end{array}$} \\
\hline & & & 316,3 & - & 326,0 & $/ 3,1$ & 317,6 & $/ 0,4$ & 317,6 & $/ 0,4$ \\
\hline & & 1 & 346,3 & - & 356,2 & $/ 2,9$ & 337,4 & $/-2,6$ & 341,1 & $/-1,5$ \\
\hline & & 5000 & 380,7 & - & 388,0 & $/ 1,9$ & 356,7 & $1-6,3$ & 367,9 & $/-3,4$ \\
\hline \multirow{3}{*}{ 2) } & \multirow{3}{*}{0,6} & 0 & 338,5 & - & 366,5 & $/ 8,3$ & 343,9 & $/ 1,6$ & 349,5 & $/ 3,2$ \\
\hline & & 1 & 384,3 & - & 407,9 & / 6,1 & 367,9 & $/-4,3$ & 386,6 & $/ 0,6$ \\
\hline & & 5000 & 420,2 & - & 440,6 & $/ 4,9$ & 385,0 & $/-8,4$ & 425,5 & $/ 1,3$ \\
\hline \multirow{3}{*}{ 3) } & \multirow{3}{*}{0,8} & 0 & 402,0 & - & 454,0 & $/ 12,9$ & 410,7 & $/ 2,2$ & 414,0 & $/ 3,0$ \\
\hline & & 1 & 405,7 & - & 438,1 & $/ 8,0$ & 383,6 & $/-5,4$ & 421,9 & $/ 4,0$ \\
\hline & & 5000 & 455,3 & - & 462,7 & $/ 1,6$ & 395,3 & $/-13,2$ & 466,0 & $/ 2,4$ \\
\hline \multirow{3}{*}{ 4) } & \multirow{3}{*}{1,0} & 0 & 728,2 & - & 698,9 & $/-4,0$ & 719,6 & $/-1,2$ & 634,6 & $/-12,9$ \\
\hline & & 1 & 601,8 & - & 658,9 & $/ 9,5$ & 543,8 & $/-9,6$ & 603,9 & $/ 0,3$ \\
\hline & & 5000 & 481,3 & - & 475,3 & $/-1,2$ & 401,2 & $/-16,6$ & 537,6 & / 11,7 \\
\hline
\end{tabular}

Table 4. . Comparison of values derived from formulas $2.3 \div 5$ and FEA [15], (load as in Fig. 6b)

\begin{tabular}{|c|c|c|c|c|c|c|c|c|c|c|}
\hline \multirow{5}{*}{$\begin{array}{l}\text { No. } \\
\text { 2) }\end{array}$} & \multirow{5}{*}{$\begin{array}{c}\psi \\
0,6\end{array}$} & \multirow{3}{*}{$\begin{array}{c}\beta \\
0\end{array}$} & \multicolumn{8}{|c|}{ Critical moment $\mathrm{M}_{\mathrm{cr}}[\mathrm{kNm}] /$ relative error $[\%]$} \\
\hline & & & \multicolumn{2}{|c|}{$\begin{array}{l}\text { LTBeam } \\
{[15]}\end{array}$} & \multicolumn{2}{|c|}{$\begin{array}{c}\text { AS } 4100[8] \\
\text { (eq. } 2.4)\end{array}$} & \multicolumn{2}{|c|}{$\begin{array}{l}\text { Serna et al.[9] } \\
\quad(\text { eq. } 2.5)\end{array}$} & \multicolumn{2}{|c|}{$\begin{array}{l}\text { AISC [6] } \\
\text { (eq. 2.3) }\end{array}$} \\
\hline & & & 334,9 & - & 354,2 & $/ 5,8$ & 339,1 & $/ 1,3$ & 345,5 & $/ 3,2$ \\
\hline & & 1 & 365,6 & - & 382,2 & $/ 4,5$ & 353,4 & $/-3,3$ & 369,9 & $/ 1,2$ \\
\hline & & 5000 & 409,2 & - & 417,7 & $/ 2,1$ & 373,2 & $/-8,8$ & 405,1 & $/-1,0$ \\
\hline \multirow{3}{*}{ 3) } & \multirow{3}{*}{0,8} & 0 & 430,8 & - & 459,3 & $/ 6,6$ & 433,3 & $/ 0,6$ & 430,0 & $/-0,2$ \\
\hline & & 1 & 398,6 & - & 417,4 & $/ 4,7$ & 382,4 & $/-4,1$ & 407,6 & $/ 2,3$ \\
\hline & & 5000 & 418,2 & - & 424,1 & $/ 1,4$ & 376,6 & $/-9,9$ & 425,5 & $/ 1,7$ \\
\hline \multirow{3}{*}{ 4) } & \multirow{3}{*}{1,0} & 0 & 630,0 & - & 672,1 & $/ 6,7$ & 614,2 & $/-2,5$ & 582,3 & $/-7,6$ \\
\hline & & 1 & 575,5 & - & 598,8 & $/ 4,0$ & 534,8 & $/-7,1$ & 531,7 & $/-7,6$ \\
\hline & & 5000 & 508,3 & - & 508,3 & $/ 0,0$ & 446,2 & $/-12,2$ & 476,7 & $1-6,2$ \\
\hline
\end{tabular}




\section{CONCLUSIONS}

In the presented paper it is shown analytical estimation of lateral-torsional critical moment of unbraced, bisymmetric, prismatic beams, with simply supports beams. Proposed method allows for determination of critical moment in case, where each load is applied in different point, with respect to height of the cross-section and has any (upward or downward) direction. It is shown, that estimation of coefficient allowing for arbitrary ordinate of load application proposed in paper Trahair et al. [7] is incorrect. In case of arbitrary distribution of bending moment along the beam, its influence on estimation of $C_{1}$ coefficient is determined on basis of values of bending moment calculated in specific sampling points: $(1 / 4),(1 / 2),(3 / 4)$ of the span of the beam and maximum

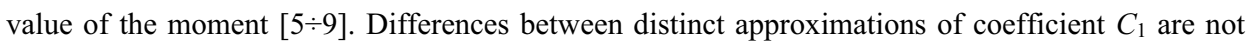
big, but judging on comparisons shown in Table 3 and Table 4, formula (2.3) seems to yield the least errors and should be used in calculations. Shown examples prove that it allows for estimation of critical moment with enough accuracy from practical point of view. 


\section{REFERENCES}

1. S.P. Timoshenko, J.M. Gere, "Theory of elastic stability”, 2nd ed., McGraw-Hill, New York, 1961.

2. M. Salvadori, "Lateral buckling of eccentrically loaded I-columns", Translacions of the ASCE, 121:1163-78, 1956.

3. D.A. Nethercot, K.C. Rockey, "A unified approach to the elastic lateral buckling of beams", The Structural Engineer, 49:321-30, 1971.

4. F. Mohri, A. Brouki, J.C. Roth, "Theoretical and numerical stability analyses of unrestrained, monosymmetric thin-walled beams", J. of Constructional Steel Research 59: 63-90, 2003.

5. P.A. Kirby, D.A. Nethercot, "Design for structural stability", Granada Publishing, Suffolk, 1979.

6. American Institute of Steel Construction (AISC), "ANSI/AISC 360-05 specification for structural buildings", Chicago, USA, 2005.

7. N.S . Trahair, M.A. Bradford, D.A. Nethercot, L. Gardner, "The behaviour and design of steel structures to EC3", Furth edition, Taylor \& Francis, London and New York, 2008.

8. Standards Australia (SA), "Steel structures. AS 4100", Sydney, Australia, 1998.

9. M.A. Serna, A. López, I. Puente, D.J. Yong, "Equivalent uniform moment factors for lateral-torsional buckling of steel members", J. of Constructional Steel Research, 60:566-580, 2006.

10. T.A. Helwig, K.H. Frank, J.A. Yura, "Lateral-torsional buckling of singly symmetric I-beams", J. Struct. Engng., ASCE, 123(9):1172-9, 1997.

11. R.Bijak, "Ogólny przypadek zwichrzenia belek o dwuteowym przekroju bisymetrycznym podpartych widełkowo, Zeszyty Naukowe Politechniki Rzeszowskiej 276, Budownictwo i Inżynieria Środowiska 58: 201208, 2011 (in polish).

12. Stahlbau-Kalender 2009, Herausgegeben von U. Kuhlman, Ernst \& Sohn, Berlin 2009 (in deutsch).

13. M. Giżejowski, "Zwichrzenie belek stalowych o ograniczonej zdolności do obrotu na podporach”, Inżynieria i Budownictwo, 10/2001 (in polish).

14. Y.L. Pi, N.S. Trahair, "Prebuckling deflections and lateral buckling - theory", J. Struct. Engng., ASCE, 118(11):2949-66, 1992

15. Y. Galéa, "Moment critique de déversement élastique de poutre fléchies - Présentation du logiciel LTBEAM", Revue Construction Métallique, CTICM, 2/2003 (in french). 


\section{LIST OF FIGURES}

Fig. 1. Designation of loads and their directions

Rys. 1 Przedstawienie typu obciążenia z uwzględnieniem kierunku

Fig. 2. Values of bending moments in eq.(2.3)

Rys. 2 Wartości momentu zginającego przyjęte we wzorze (2.3)

Fig. 3. a) Distributed load on part of the beam b) transverse load on whole beam span

Rys. 3. a) Obciążenie rozłożone na części belki b) obciążenie poprzeczne na całej długości belki

Fig. 4. Static scheme of considered beam (example 1)

Rys.4 Schemat statyczny rozpatrywanej belki (przykład 1)

Fig. 4. Static scheme of considered beam (example 2)

Rys.4 Schemat statyczny rozpatrywanej belki (przykład 2)

Fig. 6. Loading of considered example beam a) in Table 3, b) in Table 4

Fig. 6. Example 3. Static schemes of considered beam (a - Table 3, b-Table 4)

Rys.6 Przykład 3. Schematy statyczne dla rozpatrywanej belki (a z Tabeli 3, b z Tabeli 4)

Table 1. Comparison of values derived from presented work, Trahair et al [7] and FEA [15].

Tabela 1. Porównanie wyników wg prezentowanej pracy, Trahair i inni [7] z MES [15].

Table 2. Comparison of values derived from presented work and FEA [15] (Fig. 5).

Tabela 2. Porównanie wyników wg prezentowanej pracy z MES [15] (Rys.5).

Table 3. Comparison of values derived from formulas $2.3 \div 5$ and FEA [15], (load as in Fig. 6a)

Tabela 3. Porównanie wyników wg wzorów $2.3 \div 5$ z MES [15] (Rys.6a).

Table 4. Comparison of values derived from formulas $2.3 \div 5$ and FEA, (load as in Fig. $6 \mathrm{~b}$ )

Tabela 4. Porównanie wyników wg wzorów $2.3 \div 5$ z MES [15] (Rys.6b). 


\section{MOMENT KRYTYCZNY ZWICHRZENIA NIESTĘŻONYCH DWUTEOWNIKÓW BISYMETRYCZNYCH PODPARTYCH WIDELKOWO}

Slowa kluczowe: moment krytyczny zwichrzenia, wzory analityczne, podparcie widełkowe, pryzmatyczne bisymetryczne belki dwuteowe

\section{STRESZCZENIE:}

W pracy przedstawiono analityczne oszacowanie momentu krytycznego zwichrzenia niestężonych, bisymetrycznych belek dwuteowych podpartych widełkowo. W metodach analitycznych szacowania momentu krytycznego zwichrzenia można wyróżnić trzy problemy: (1) uwzględnienie warunków brzegowych na końcach rozpatrywanego elementu, (2) oszacowanie wpływu nieliniowego rozkładu momentu zginającego wzdłuż długości elementu oraz (3) poprawnego uwzględnienia miejsca przyłożenia obciążenia poprzecznego po wysokości przekroju poprzecznego dla dowolnego schematu statycznego. Trzeci z wymienionych problemów jest najtrudniejszy i był rozwiązany niepoprawnie w pracy Trahair i inni [7] (2.6), w której przyjęto wzór poprawny jedynie dla przypadku obciążenia poprzecznego bez momentów skupionych.

W tym opracowaniu analizowano przypadek podparcia widełkowego, przyjmowany w praktyce projektowej najczęściej. Wpływ nieliniowego rozkładu momentu zginającego uwzględniono na podstawie momentów w (1/4), (1/2), (3/4) rozpiętości belki oraz maksymalnej wartości bezwzględnej momentu zginającego w belce $M_{0}$. Rozpatrzono trzy wzory aproksymacyjne współczynnika $C_{1}$ uwzględniającego ten rozkład. Wzór (2.3) jest pewną modyfikacją zależności przedstawionej przez Kirby, Nethercot [5] i jest zawarty w AISC [6]. Z kolei norma australijska AS 4100 korzysta z zależności (2.4) analogicznej do wzoru przedstawionego przez Trahair et al.[7]. Stosunkowo niedawno Serna et al. [9] przedstawili wzór aproksymacyjny (2.5). W celu oszacowania wpływu miejsca przyłożenia obciążenia po wysokości przekroju rozpatrujemy równanie różniczkowe giętno-skrętnej utraty stateczności pryzmatycznej belki o przekroju bisymetrycznym. Po uwzględnieniu warunków brzegowych podparcia widełkowego na końcach otrzymujemy równanie różniczkowe w funkcji kąta skręcenia $\varphi(x)$ dla belki obciążonej momentami skupionymi na końcach oraz obciążeniem poprzecznym w przęśle (rys.1). Każde z obciążeń skupionych i rozłożonych może mieć różną współrzędną przyłożenia siły po wysokości przekroju poprzecznego. Obciążenie rozłożone, w ogólnym przypadku, może mieć dowolny rozkład i występować tylko na części rozpatrywanej belki. Istotnym wyróżnikiem pracy w stosunku do publikacji innych autorów jest wyprowadzenie wzoru na współczynnik uwzględniający rzędną miejsca przyłożenia obciążenia poprzecznego po wysokości przekroju dla dowolnego schematu statycznego. W porównaniu z wcześniejszą pracą autora [11], rozszerzenie polega z kolei na tym, że każde z obciążeń poprzecznych może być przyłożonej na dowolnej rzędnej po wysokości przekroju.

W celu oszacowania momentu krytycznego zwichrzenia wykorzystamy metodę ortogonalizacji Bubnowa-Galerkina, aproksymując kąt skręcenia przekroju za pomocą jednego wyrazu szeregu. Istotą zaproponowanego rozwiązania jest takie przekształcenie równania różniczkowego (3.1), aby jego współczynniki nie zależały od przyrostu momentu $M_{0}$. (tj. maksymalnej wartości bezwzględnej momentu zginającego w bece). Wykorzystamy tu tę właściwość, że $M_{\mathrm{y}}(x) / M_{0}$, $q_{z}(x) / M_{0}$ oraz $Q_{k} / M_{0}$ nie zmieniają się wraz ze wzrostem obciążenia. Po wykonaniu odpowiednich dla metody Bubnowa-Galerkina przekształceń otrzymujemy równanie kwadratowe (3.3). Rozwiązaniem równania kwadratowego jest zależność na moment krytyczny zwichrzenia (3.9). Postać wzoru jest analogiczna do powszechnie przyjętej w praktyce projektowej zależności (2.1). Najistotniejszą częścią prezentowanej pracy jest przedstawienie wzoru na 
współczynnik $C_{2}(3.7 \mathrm{~b}, 3.5)$, pozwalający uwzględnić wpływ miejsca przyłożenia obciążenia poprzecznego po wysokości przekroju oraz jego znaku dla dowolnego schematu statycznego. W przypadku obciążenia przedstawionego na Rys. 3 wzór (3.5) upraszcza się odpowiednio do zależności (3.11) i (3.12). W przykładach przedstawionych w dalszej części pracy współczynnik $C_{2}$ wyznaczamy ze wzorów (3.7b) i (3.12).

W pierwszym przykładzie rozpatrzono belkę wykonaną z IPE500, o rozpiętości $L=8 \mathrm{~m}$. Obciążenie poprzeczne jest przyłożone do górnej półki. Schemat statyczny pokazano na Rys. 4. W Tablicy 1 porównano momenty krytyczne zwichrzenia otrzymane za pomocą zależności $(3.7 \mathrm{~b}, 3.12)$ prezentowanej metody oraz pracy Trahair i inni [7] (2.6) z rozwiązaniami MES [15]. Pokazano istotny błąd (ok. 50\%) metody przedstawionej przez Trahair i inni [7].

W drugim przykładzie porównano momenty krytyczne zwichrzenia otrzymane za pomocą zależności (3.7b, 3.12) prezentowanej metody z rozwiązaniami MES [15]. Schemat statyczny pokazano na rys. 5. Obciążenie rozłożone jest przyłożone do górnej półki. Rozpatrzono dwa przypadki obciążenia siłą skupioną (obciążenie przyłożone odpowiednio do górnej i dolnej półki). Wyniki przedstawione w tablicy 2 pokazują bardzo dobrą zgodność wyników analitycznych z rozwiązaniami MES [15].

W trzecim przykładzie oszacowano błędy w aproksymacji współczynnika $C_{1}$, uwzględniającego nieliniowy rozkład momentu zginającego, wynikające z przyjęcia wzorów $(2.3 \div 2.5)$. Obciążenie poprzeczne jest przyłożone do środka ciężkości $G$. W tym przypadku $\left(z_{\mathrm{A}}=z_{1}=0\right)$ wzór na moment krytyczny (2.1) upraszcza się do zależności (4.1). Parametry opisujące schemat statyczny belki skonstruowano w taki sposób, by można było uwzględnić zarówno przypadek dominującego wpływu obciążenia skupionego jak i obciążenia rozłożonego. Wprowadzamy parametr $\beta$ (4.2c), który dla $\beta=0$ oznacza brak siły skupionej, a dla bardzo dużych wartości niewielki wpływ obciążenia rozłożonego. Z kolei parametr $\psi(4.2 \mathrm{~d})$ określa stopień utwierdzenia na podporze ( $\psi=0$ to przegub, $\psi=1$ pełne utwierdzenie). Porównanie wyników zawartych w tabeli 3 i 4 pokazuje stosunkowo małe błędy aproksymacji momentu krytycznego wykorzystujące wzory $(2.3 \div 5)$. Należy pamiętać, że błędy w wyznaczeniu współczynnika zwichrzenia byłyby jeszcze mniejsze. Wyniki otrzymane na podstawie wzoru (2.3) wydają się jednak obarczone najmniejszym błędem.

Podsumowując powyższe, wyprowadzone wzory analityczne pozwalają na prostą i szybką kontrolę poprawności momentu krytycznego oszacowanego za pomocą MES [15]. 